\title{
Pancreas/Duodenum Homeobox Protein
}

1

National Cancer Institute

\section{Source}

National Cancer Institute. Pancreas/Duodenum Homeobox Protein 1. NCI Thesaurus. Code $C 118249$

Pancreas/duodenum homeobox protein 1 (283 aa, $\sim 31 \mathrm{kDa}$ ) is encoded by the human PDX1 gene. This protein plays a role in the modulation of insulin expression. 